\title{
SELECTED BUYING BEHAVIOURS OF CATTLE BREEDERS ON THE POLISH INDUSTRIAL FEED MARKET
}

\author{
Monika Szafranska ${ }^{1}$, Dr. Ing. \\ ${ }^{1}$ University of Agriculture in Krakow, Poland
}

\begin{abstract}
The buying behaviours of purchasers of industrial feed are still not researched. Researchers have been focusing mostly on the consumer goods and services market. Therefore, the aim of the paper is to identify and characterise selected buying behaviours of cattle breeders on the Polish industrial feed market. The knowledge of purchaser's behaviours shaping their choice, apart from its cognitive dimension, may be used to design marketing actions in feed businesses effectively and reduce the vulnerability of their position on the Polish feed market. The main source of data used was primary information from author's own study (the PAPI method, a group of 200 cattle breeders from the Malopolska Province). The statistical analysis of the studied material encompassed aggregate statistical indicators as well as the non-parametric test "chi square". Results of studies were presented in a descriptive and graphic form. The conducted analysis shows that $85 \%$ of farmers buying industrial feed use indirect distribution channels. Owners of the smallest stocks are the most likely to buy feed in outlets. Medium and large stock owners use direct channels due to order sizes. The most important factors for choosing industrial feeds are price, good location, and payment conditions.
\end{abstract}

Key words: cattle breeders, industrial feed, buying behaviours.

JEL code: M31, Q12, Q13

\section{Introduction}

The most important factor in animal production not only for production results, but also for the quality of the products, is the correct feeding of the animals. Rational feeding consists of providing all nutrients in the feed and covering the needs of animals depending on the direction of animal production (Dinev D. et al., 2003; Feldt T. et al., 2016). Farm feed, agri-food industry waste, and industrial feed can be used for this purpose (Piwowar A., 2013).

The industrial feed market is one of the most dynamically developing agricultural production means markets in Poland. It is characterised by a continuously changing structure of supply. Foreign feed companies intensify their marketing activities in Poland and those already operating are subject to diverse transformations. The effect of the process of internationalisation of the feed sector is the increase of competitiveness (Piwowar A., 2013; Ploplis E., 2017; Rynek pasz..., 2017). Competition in such a dynamic and internationalised environment requires understanding diverse attitudes of purchasers. The attitudes of purchasers towards the products offered on the market often have a significant impact on their purchase decisions and, in consequence, on the success of a given institution.

Purchasers' behaviours on the production means market include all subjectively and objectively defined rational and emotional behaviours during the purchase decision-making process. The buying behaviours of purchasers of industrial feed are still not researched. Researchers have been focusing mostly on the consumer goods and services market. The market of production means, including the industrial feed market, its meaning and specificity, which often needs a separate marketing approach, has not been discussed much. This is due mostly to a smaller number of entities on this market, lower number of transactions, and a different trade in goods structure (Wojciechowski T., 2003; Kubon M., 2006).

Therefore, the aim of the paper is to identify and characterise selected buying behaviours of cattle breeders on the Polish industrial feed market. The knowledge of purchaser's behaviours shaping their choice, apart from its cognitive dimension, may be used to design marketing actions 
in feed businesses effectively and reduce the vulnerability of their position on the Polish feed market.

Breeder's behaviours concerning buying industrial feed were presented considering variables such as demographics, stock size, and distribution channel (direct/indirect). In order to characterise the buying behaviours of cattle breeders on the feed market, the author used the following research questions.

- What kinds of cattle feed do breeders buy?

- What determines the choice of a retail establishment as a place to buy industrial feed?

- How often do cattle breeders buy industrial feed?

- Which demographic traits of the breeders affects their buying behaviours on the feed market?

The main source of data used was primary information from author's own study. The research was conducted in 2017 using the PAPI method on a group of 200 cattle breeders from the Malopolska Province. In 2013, the number of bovine holdings in the analysed province was 42.200 (Urzad Statystyczny, 2014). Purposive sampling was used. To estimate the minimal sample size, the following formula was used (Szreder M., 2004):

$$
n=\frac{\frac{1}{4} \cdot N}{N \cdot \frac{d^{2}}{z_{\alpha / 2}^{2}}+\frac{1}{4}}
$$

Where:

$N$ - population size;

$d$ - statistical error;

$z_{a / 2}$ - the value of random variable $Z$ of normal standard distribution.

The maximal value of the statistical error of the result was assumed as $5 \%$. The necessary minimal sample size was determined as 101 persons. 210 breeders participated in the study. After excluding inconsistent and incorrectly filled questionnaires, data from 200 questionnaires was further analysed.

The questionnaire was divided into two parts and consisted of 21 questions in total. Most of the questions were closed, only two were open. The first part contained questions regarding buying behaviours of cattle breeders on the industrial feed market. The second part contained the respondent's particulars.

The interview was conducted with dairy and beef cattle breeders. $30 \%$ of the respondents were women and $70 \%$ were men. Only adult persons (over 18 years of age) participated in the study. Over $50 \%$ of the respondents were between 18 and 35 years old. The two remaining groups of participants were middle-aged ( $23 \%$ ) and elderly ( $23 \%)$. The majority of the studied group declared secondary education. Persons with basic vocational education constituted $25 \%$ of the studied group. The remaining respondents declared tertiary education. Every second breeder has kept cattle for less than 5 years and every third for 5-10 years. The remaining respondents have done it for between 11 and 30 years. The analysed group of breeders usually kept stocks of up to 19 animals (44\%). The dominance of the smallest stocks is determined by the area where the research was conducted. The Malopolskie Province is characterised by the smallest average number of cows per holding in Poland (The results of.., 2017). In $40 \%$ of holdings, the stocks consisted of 20-29 animals. The remaining holdings had 30 or more cows. 
The statistical analysis of the studied material encompassed aggregate statistical indicators as well as the non-parametric test "chi square" $\left(\mathrm{X}^{2}\right)$ allowing for an assessment of the significance of relationship between variables if at least one of them is non-measurable. All hypotheses were verified on the significance level $a=0.05$.

The trade credit interest rate was calculated based on the following formula (Bien W., 2008):

$$
d=\frac{s \cdot 100}{100-s} \cdot \frac{365}{t}
$$

Where:

$s$ - discount rate ( \% of rebate);

$t$ - credit period (difference between the deferred payment term and cash payment term).

Apart from the primary sources they also used secondary sources which encompassed both domestic as well as foreign literature. Results of studies were presented in a descriptive and graphic form.

\section{Factors determining the buying behaviours of cattle breeders on the Polish industrial feed market}

Farm feed, agri-food industry waste, and industrial feed are used to feed cattle. The first group includes all feed manufactured in an agricultural holding, such as hay, field crop forage and silage, as well as cereals and legume seeds. Agri-food industry waste from sugar refineries, distilleries, oil mills, and mills can also be used to feed cattle (Alcaide E., 1996; Feltes M., et al., 2010). Due to diverse nutritional requirements of different farm animals' species, varieties, and functional types within particular species, industrial compounds supplementing farm feeds are used. Animal producers can also use complete industrial compounds. Industrial feeds make feeding easier and guarantee a fixed quality. Modern technologies used in industrial processing are based not only on chemical, but also on biotechnological processes. They allow for creating compounds and preparations improving the productivity and health of animals, as well as the extension or improvement of feed utility (Piwowar A., 2013).

Industrial cattle feed includes complete, complementary, and mineral feed compounds, milk replacers, and pre-mixtures calculated per $1 \%$. According to the research conducted (Fig. 1.), breeders mostly bought complementary feed compounds (93\%). These compounds were mostly energy and protein concentrates and equalizers. Almost $70 \%$ of breeders bought mineral feed compounds. $62 \%$ used complete industrial compounds. Almost every tenth respondents fed calves with milk replacers. Only $1 \%$ of breeders bought pre-mixtures calculated per $1 \%$. The low percentage share of this type of industrial feed in the overall structure of purchased feed is due to the fact that only farms having an identification number issued in accordance with the Regulation (EC) No 183/2005 of the European Parliament and of the Council of 12 January 2005 laying down requirements for feed hygiene (Official Journal of ..., 2005) are able to purchase it. 


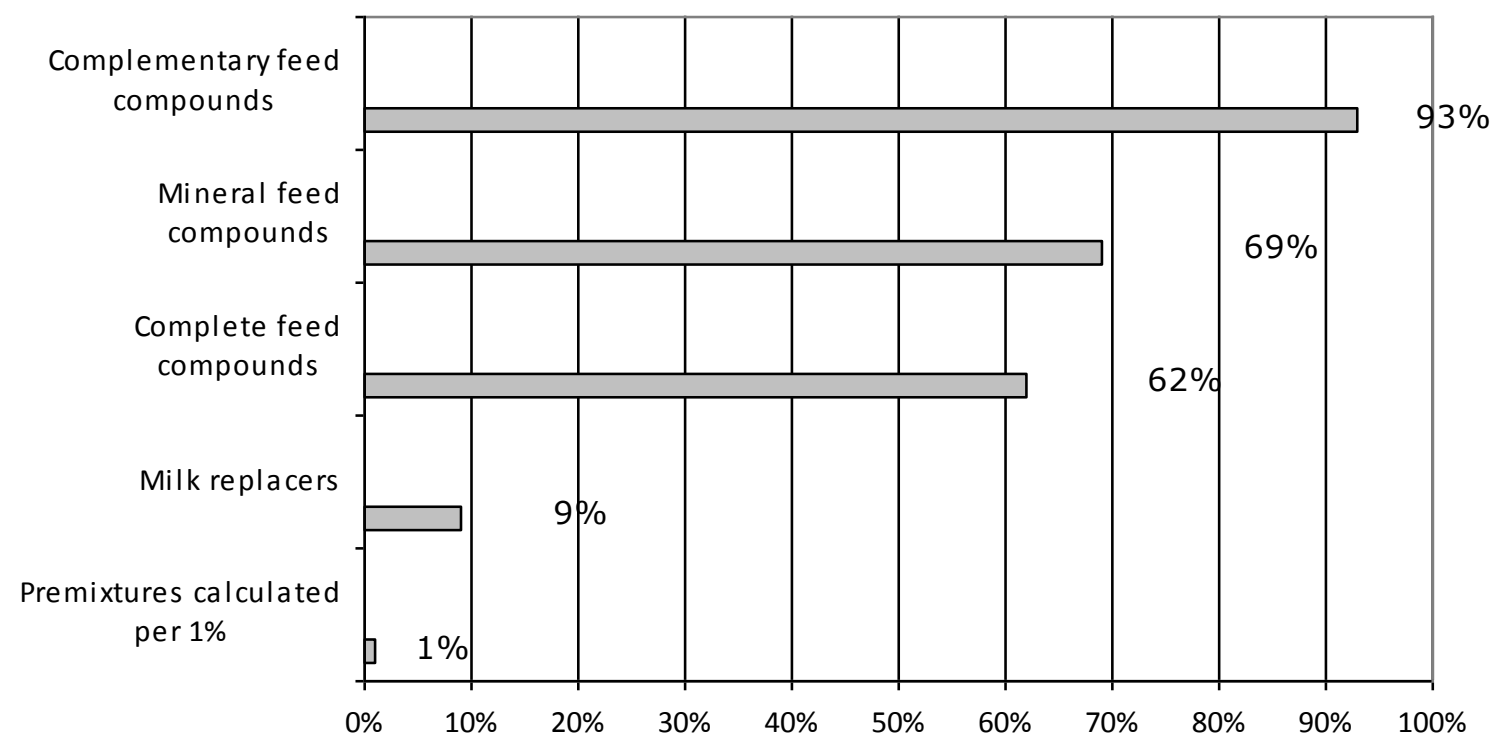

Source: autor's research, $n=200$, multiple choice

Fig. 1. Industrial feeds purchased by cattle breeders

The conducted analysis shows that $85 \%$ of farmers buying industrial feed use indirect distribution channels. The remaining breeders bought feed directly from companies producing feed. The choice of the place of purchase is determined by stock size $\left(X^{2}=30.4 ; d f=2\right)$. Owners of the smallest stocks are the most likely to buy feed in outlets. Medium and large stock owners use direct channels due to order sizes. To buy feed directly from Polish producers, one has to purchase at least 3-5 tons (the minimum amount is established by each producer).

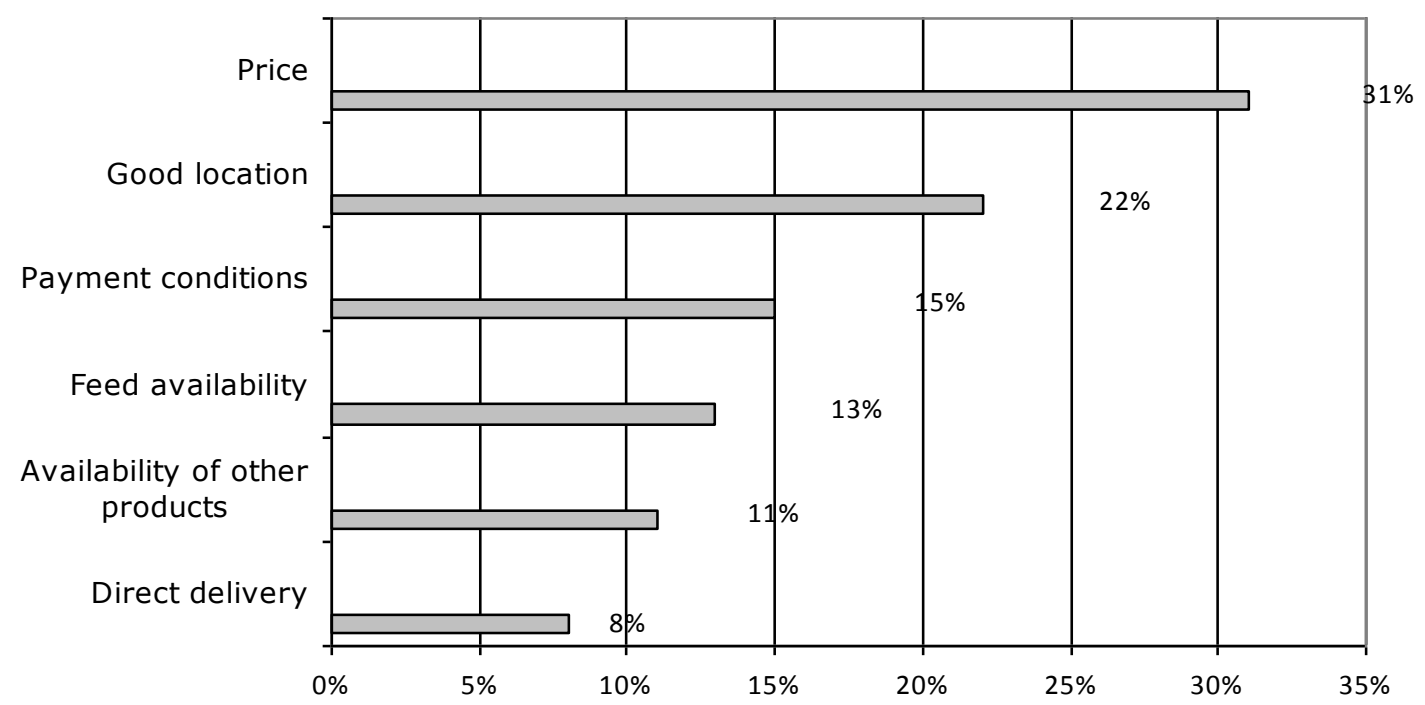

Source: autor's research, $n=200$

Fig. 2. The most important factors for choosing industrial feeds

The most important factor for choosing an industrial feed outlet is price (31\% of answers). The obtained results are not surprising, as dairy cattle feeding costs are dominant in aggregate costs. The results are consistent with those obtained by other scholars (Norton N. et al., 1997; Khakbazan M., et.al, 2015; Berger H. et al., 2017; Oguz C. and Yener A., 2017). The conducted statistical analysis demonstrates that declaring the price as the most important factor for the 
choice of purchase place was not determined by the demographic characteristics of the respondents (gender; $X^{2}=1.0 ; d f=1$; education; $X^{2}=0.9 ; d f=2 ;$ age; $\left(X^{2}=2.9 ; d f=2\right)$. Also did not depend on stock size $\left(x^{2}=0.8 ; d f=2\right)$ or distribution channel $\left(x^{2}=3.1 ; d f=1\right)$ either.

Good location was the second factor determining the choice of purchase place (22\%). According to statistical analysis, a good outlet location was important for women $\left(X^{2}=5.3 ; d f=1\right)$ and the oldest respondents $\left(X^{2}=27.5 ; d f=2\right)$. For $2 / 3$ of people over 55 years of age, location was important when choosing an outlet. It was determined that the significance of this factor decreases with the increase of purchasers' education level. This determinant was important for all purchasers with a basic vocational education. Every fifth respondent with a secondary education chose this factor. No respondent holding a university degree chose this option. Due to the fact that the minimum number of answers in contingency tables should be higher than 5 observations, verification using the $x^{2}$ test was not performed. Given the distribution channel, this factor was important for breeders buying feed from intermediaries $\left(X^{2}=30.4 ; d f=1\right)$. This was not relevant for those using direct marketing channels. Due to the fact that the distribution channel type is determined by production size, the bigger the stock, the less important the location $\left(X^{2}=35.2\right.$; $d f=2$ ).

The breeders also pointed to favourable payment conditions (15\%), concerning mostly the opportunity of using a trade credit and discounts for cash payments. Trade credits allow a deferral of payment for purchased goods to a date agreed upon with the supplier. Production means suppliers consider credit an instrument of sale and profit increase (Cao F. et. al., 2018; Chod J., 2017; Tsao Y., 2017). The conducted research shows that when buying feed, breeders most often use trade credit, the date of payment of which is 1 month (30 days) on average. Almost every third respondent paid in cash, mostly due to the possibility of obtaining a rebate (discount), which was $2 \%$ for cash payment. The remaining respondents chose payment terms within between 2 and 10 days, which gave them a $1 \%$ discount.

According to the research, the main reason for which the breeders prefer a trade credit is their belief that it is free. A simple calculation demonstrates that trade credit not only is not free, but in most cases, may be much more expensive than a bank credit (Bien W., 2008). The starting point for calculating the price of the offered trade credit is always the discount the purchaser can get. In the discussed case, the interest rate on credits offered to breeders was $25.69 \%$ (payment within 30 days) and $18.43 \%$ (payment within 10 days). The average annual percentage rate of charge for overdrafts for farmers for 20.10 .2017 was $11.95 \%$ in Poland. Thus, the cost of an alternative bank credit is much lower. This factor was important for the youngest breeders $\left(X^{2}=78.6 ; d f=2\right)$, men $\left(x^{2}=76.9 ; d f=1\right)$, respondents with a higher education $\left(x^{2}=21.4 ; d f=2\right)$, and breeders buying feed directly from the manufacturer $\left(X^{2}=63.4 ; d f=1\right)$.

Feed availability was important for $13 \%$ of the respondents. Statistical analysis shows that this factor is important for men $\left(X^{2}=30.1 ; d f=1\right)$, the oldest and the youngest breeders $\left(X^{2}=67.6\right.$; $d f=2)$, and for people with a basic vocational and higher education $\left(x^{2}=56.1 ; d f=2\right)$, as well as for owners of larger stocks $\left(X^{2}=29.4 ; d f=2\right)$ and users of direct distribution channels $\left(X^{2}=34.0 ; d f=1\right)$.

Feed availability in outlets is necessary for proper inventory management in an agricultural holding, which directly depends on delivery frequency (Cardoso V. et al., 2014). The conducted research shows that most farmers order feed every two weeks (50\% answers) and $42 \%$ of breeders order feed once a month. Less than $10 \%$ buy feed once a week. 
The respondents declare that the most popular way of ordering is via telephone ( $46 \%$ of breeders). Almost $40 \%$ of farmers buy feed in outlets. They are mostly smaller stock owners and indirect distribution channels users. The remaining respondents use e-mail for this purpose (16\%).

The availability of other products needed on a farm in an outlet is also important for breeders (11\% of answers). The statistical analysis demonstrates that the importance of this factors depends on education $\left(X^{2}=60.4 ; d f=2\right)$, respondents' age $\left(X^{2}=67.6 ; d f=2\right)$, and stock size $\left(X^{2}=17.2 ; d f=2\right)$. The least educated, the oldest, and owners of the smallest stocks chose this option most frequently.

Almost every tenth respondent indicated the possibility of direct delivery of the feed to the holding included in the price. It allows the farmers to save time and reduce transport costs. It was important for men $\left(X^{2}=54.3 ; d f=1\right)$, middle-aged respondents $\left(X^{2}=41.9 ; d f=2\right)$, and persons with a higher education $\left(x^{2}=18.3 ; d f=2\right)$. These persons owned the largest stocks $\left(x^{2}=31.4 ; d f=2\right)$ and used direct distribution channels the most frequently $\left(X^{2}=24.2 ; d f=1\right)$.

\section{Conclusions, proposals, recommendations}

1) The breeder decides where to buy feed. The decision is determined by many factors, the most important of which are price, good location, and payment conditions. The conducted research shows that almost every third breeder considers price when buying feed. Price is the only motive not determined by demographic characteristics of the respondents. The remaining motives depended on gender, age, and education level of the breeders, as well as on stock size.

2) When discussing feed price as a factor determining the place of purchase, companies selling feed should also consider the expectations of potential buyers regarding discounts, e.g. for payments in cash. According to the research, it is one of the most important factors for the choice of payment term.

3) The convenient location of a feed outlet is important mainly for smaller holdings, which mainly use indirect distribution channels. This is of less importance for larger entities that use direct distribution channels. Currently, feed producers are more likely to offer feed delivery directly and cover all logistics costs. In such a case, the location is less important as long as the products are delivered on time.

4) The easiness of direct contact, an important factor of advantage of suppliers located closer to holdings, has lost some of its significance due to the dynamic development of modern means of communication. The conducted research shows that currently, almost $2 / 3$ of breeders order feed via telephone or e-mail.

5) Another important factor affecting farmers' buying behaviours is feed availability in an outlet. Almost $13 \%$ of breeders participating in the study were dissatisfied with feed availability. Therefore, the improvement of actions related to assortment structure and feed distribution through indirect channels is needed. Properly functioning feed distribution channels should assure an appropriate amount of products meeting consumers' demand.

6) Given the high variability of buying behaviours on the market and their susceptibility to diverse factors, it would be interesting to study the dynamics and directions of these changes in the future.

\section{Bibliography}

1. Ambler, T. (1999). Marketing od A do Z (Marketing from A to Z). Wydawnictwo Profesjonalnej Szkoly Biznesu, Krakow, pp. 337-338. 
2. Bień, W. (2008). Zarządzanie finansami przedsiębiorstwa (Business Finance Management) Difin, Warszawa, p. 365.

3. Business Tendency Surveys. A Handbook (2003). Paris: OECD, p. 127.

4. Fontagne, L., Gourdon, J., Jean, S. (2013). Transatlantic Trade: Whither Partnership, Which Economic Consequences? CEPII - Policy Brief, September, No. 1, p. 4.

5. Forgacs, C. (2006). A mezogazdasagi kistermelok jovoje az atalakulo mezogazdasagi piacokon (Future of Smallholdings in Regoverning Markets). Gazdalkodas. No. 6. pp. 29-41.

6. Karanassou, M., Sala, H., Salvador, P. F. (2007). Capital Accumulation and Unemployment: New Insights on the Nordic Experience. IZA Discussion Paper, 3066. Retrieved: http://ssrn.com/abstract=1025889. Access: 16.09.2012.

7. Kohaliku omavalitsuse uksuste voimekuse indeks 2013 (Local Governments Capacity Index 2013) (2014). Geomedia. 57 p. Retrieved: http://www.fin.ee/public/KOV/ Uuringud_ja_analuusid/2014_kov_voimekuse_ indeks_loppversioon.pdf. Access: 15.11.2015.

8. Makuteniene, D. (2004). Zemes naudojimo intensyvumo priklausomybe nuo ukininku ukiu dydzio Lietuvoje (Land Use Intensity Dependence on the Size of Farmers Farms in Lithuania). Vagos: LZUU mokslo darbai, Volume 18, Issue 65, pp. 60-69.

9. Maszynowa Wspolnota w Unii Europejskiej (Machinery Community in the European Union) (2002). Retrieved: http://www.ppr.pl/artykul-maszynowa-wspolnota-w-unii-europejskiej-20152-dzial-9.php Access: 10.12.2015.

10. Orlova, U. L. (2013). Socialiai globojamu vyresnio amziaus asmenu gyvenimo kokybes veiksniai (The Quality of Life Factors of Assisted Elderly People). Gerontologija 2013; 14(2), pp. 96-105.

11. Pajtinkova Bartakova, G., Gubiniova, K. (2012). Udrzatelny marketingovy manazment (Sustainable Marketing Management). Trencin: Institut aplikovaneho manazmentu. p. 241.

12. Phelps, E. S. (1972). Inflation Policy and Unemployment Theory. New York: Norton. p. 322.

13. Pietrzak, M., Roman, M., (2014). Rozwoj transportu jako sila napedowa procesow globalizacji i regionalizacji miedzynarodowej (Development of Transport as a Driving Force of Globalization and Regionalization of the Economy), Logistyka 4/2014, pp. 3639-3648.

14. Pukenas, K. (2009). Kokybiniu duomenu analize SPSS programa: mokomoji knyga (Qualitative Data Analysis Using SPSS Programme: Teaching Book). Lietuvos kuno kulturos akademija. Kaunas: LKKA. p. 93.

15. Racine, J.B. Reymond, H. (1977). Analiza Ilosciowa w Geografii (Quantitative Analysis in Geography). PWN, Warszawa, p. 254.

16. Sepp, V., Noorkoiv, R., Loodla, K. (2009). Eesti kohaliku omavalitsuse uksuste voimekuse indeks: metoodika ja tulemused, 2005-2008 (Estonian Local Government Capacity Index: Methods and Results, 2005-2008). In "Cities and Rural Municipalities in Figures 2009". Statistics Estonia. pp. 10-42.

17. Soufani, K. (2002). On the Determinants of Factoring as a Financing Choice: Evidence from the UK. Journal of Economics and Business, Volume 54, Issue 2, pp. 239-252.

18. Varnik, R. (2008). Piima kokkuostuhind jaab tootmiskuludele alla (Purchase Price of Milk Falls below the Cost of Production). Maamajandus, Volume 2008, pp. 18-21.

19. Wojewodzka-Wiewiorska, A. (2014). Dynamika rozwoju spoleczno-ekonomicznego gmin wiejskich wojewodztwa mazowieckiego na tle innych typow gmin (Dynamics of the Socio-Economic Development of Rural Communes Relating to Other Types of Communes in the Masovian Voivodeship). Journal of Agribusiness and Rural Development 2014, no 2, pp. 213-223.

20. Zvinkliene, A. (2012). Socialine lygiu galimybiu kontrolieriaus tarnybos refleksija: Lietuvos "Web 2.0 bendruomenes" atvejis (Social Reflection on the Office of the Equal Opportunities Ombudsperson: Case of Lithuanian Web 2.0 Community). Lyciu studijos ir tyrimai, No. 10, pp. 60-70. 